\title{
Supreme Court of the efmited States
}

Donald J. TRump, PResident of the United States, ET AL., PETITIONERS,

V.

STATE OF HAWAII, ET AL., RESPONDENTS.

On Writ of Certiorari to the United States Court of Appeals for the Ninth Circuit

\section{BRIEF OF LABOR ORGANIZATIONS AS AMICI CURIAE SUPPORTING RESPONDENTS}

NICOLE G. BERNER

DEBORAH L. SMITH

LEO GERTNER

SERVICE EMPLOYEES

INTERNATIONAL UNION

1800 Massachusetts Ave.,

NW

Washington, DC 20036

debbie.smith@seiu.org

Attorneys for Amicus

Curiae SEIU
BARBARA J. CHISHOLM

Counsel of Record

KRISTIN M. GARCÍA

ALTSHULER BERZON LLP

177 Post Street, Ste.

300

San Francisco, CA 94108

(415) 421-7151

bchisholm@altber.com

Attorneys for Amici Curiae 
JUDITH RIVLIN

AMERICAN FEDERATION OF

STATE, COUNTY AND

MUNICIPAL EMPLOYEES 1101 17th St., NW, Suite 900

Washington, DC 20036

jrivlin@afscme.org

Attorney for Amicus

Curiae AFSCME

DAVID J. STROM

AMERICAN FEDERATION OF TEACHERS,

555 New Jersey Ave., NW

Washington, DC 20001

dstrom@aft.org

Attorney for Amicus

Curiae AFT

JODY CALEMINE

COMMUNICATIONS

WORKERS OF AMERICA

501 3rd St., NW

Washington, DC 20001

jcalemine@cwa-union.org

Attorney for Amicus

Curiae CWA

ALICE O'BRIEN

EMMA LEHENY

LUBNA A. ALAM

NATIONAL EDUCATION

ASSOCIATION

$120116^{\text {th }}$ Street, NW,

Suite 819

Washington, D.C. 20036-

3290

aobrien@nea.org

Attorneys for Amicus

Curiae NEA
NIRAJ R. GANATRA

AVA BARBOUR

INTERNATIONAL UNION, UNITED AUTOMOBILE, AEROSPACE AND AGRICULTURAL IMPLEMENT WORKERS OF AMERICA (UAW) 8000 E. Jefferson Ave.

Detroit, MI 48214 nganatra@uaw.net abarbour@uaw.net Attorneys for Amicus Curiae UAW

MARIO MARTÍNEZ MARTÍNEZ AGUILASOCHO \& LYNCH, APLC 1527 19th St., Suite 332 Bakersfield, CA 93301 mmartinez@farmworkerla w.com

Attorney for Amicus Curiae UFW

NiCHOLAS CLARK UNITED FOOD AND COMMERCIAL WORKERS 1775 K Street, NW Washington, DC 20006 nclark@ufcw.org Attorney for Amicus Curiae UFCW 


\section{TABLE OF CONTENTS}

TABLE OF AUTHORITIES ......................................ii

INTERESTS OF AMICI CURIAE .............................

INTRODUCTION AND SUMMARY OF

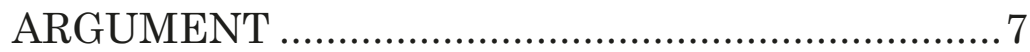

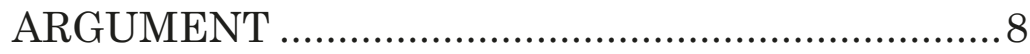

I. The Challenged Proclamation Causes

Irreparable Harm By Separating Citizens

And Immigrants From Family Members

Abroad

A. Compelled Family Separation Causes

Negative Physical and Mental Health

Consequences....

8

B. Amici's Members Have Suffered the

Harm of Forced Family Separation

II. The Proclamation Sends A State-

Sponsored Message That Promotes Anti-

Muslim Hostility, Discrimination, And

Stigma

A. The Muslim Travel Ban Has Led to Increased Violence and Discrimination Against Muslims.

B. Anti-Muslim Hostility and

Discrimination Adversely Affects

Mental and Physical Health.

C. Amici's Members Have Suffered from the Proclamation's Anti-Muslim

Message.

CONCLUSION 


\section{TABLE OF AUTHORITIES}

\section{Federal Circuit Court Cases}

Legal Assistance for Vietnamese Asylum

Seekers v. Dep't of State,

45 F.3d 469 (D.C. Cir. 1995) .............................. 18

\section{Federal Rules, Regulations and Orders}

Executive Order 13769, 82 Fed. Reg. 8977

(Jan. 27, 2017)..........................................passim

Executive Order 13780, 82 Fed. Reg. 13209

(Mar. 9, 2017) ............................................passim

Presidential Proclamation 9645, 82 Fed. Reg.

45,161 (Sept. 27, 2017) ...............................passim

\section{Other Authorities}

2017 on Track to Becoming One of the Worst

Years Ever for Anti-Muslim Hate Crimes,

CAIR (Oct. 11, 2017),

http://islamophobia.org/articles/ 209-2017-on-

track-to-becoming-one-of-the-worst-years-

ever-for-anti-muslim-hate-crimes.html

Sawssan R. Ahmed et al., A Structural Model of

Racial Discrimination, Acculturative Stress, and Cultural Resources Among Arab American Adolescents, 48 Am. J. Cmty. Psych. 181 (2011).

David K. Androff et al., U.S. Immigration Policy and Immigrant Children's Well-being: The Impact of Policy Shifts, 38(1) J. of Soc. \& Welfare 77 (2011) 
Anti-Muslim Activities in the United States, New America, https://www.newamerica.org/indepth/anti-muslim-activity/ (last visited Mar. $22,2018)$

CAIR 3rd Quarter Civil Rights Report Shows Rise in Hate Crimes Over Same Period Last Year, Moderate Decline in Total Cases, CAIR (Oct. 25, 2017), http://cair.com/presscenter/press-releases/14715-cair-3rd-quartercivil-rights-report-shows-rise-in-hate-crimesover-same-period-last-year-moderate-declinein-total-cases.html

CAIR Calls for Hate Crime Probe for Racist Harassment Targeting Tenn. Muslim Girls, Knife Attack on Father, Threat to Kill Entire Family, CAIR (Oct. 25, 2017), https://www.cair.com/press-center/pressreleases/14735-cair-calls-for-hate-crimeprobe-of-racist-harassment-targeting-tennmuslim-girls-knife-attack-on-father-threat-tokill-entire-family.html

Rebecca A. Clay, Islamophobia: Psychologists Are Studying the Impact of Anti-Muslim Sentiment and Exploring Ways To Prevent It, 48(4) Monitor on Psychol. 34 (Apr. 2017) 19,22

Karlijn Haagsman et al., Transnational Families and the Subjective Well-Being of Migrant Parents: Angolan and Nigerian Parents in the Netherlands, 38:15 Ethnic \& Racial Stud. 2652 (2015)

Dena Hassouneh, Anti-Muslim Racism and Women's Health, 26(5) J. of Women's Health 401 (2017) 
Sarah Horton, A Mother's Heart Is Weighed

Down with Stones: A Phenomenological Approach to the Experience of Transnational Motherhood, 33 Culture, Med., \& Psychiatry 21 (2009) 8

Jeanne Miranda et al., Depression Among Latina

Immigrant Mothers Separated from their

Children, 56(6) Psychiatric Servs. 717 (2005) ..... 9

Mislabeled: The Impact of School Bullying and

Discrimination on California Muslim

Students, CAIR California (2015),

https://ca.cair.com/sfba/wp-content/

uploads/2015/10/CAIR-CA-2015-Bullying-

Report-Web.pdf ......................................... 24

Dalia Mogahed \& Youssef Chouhoud, American Muslim Poll 2017: Muslims at the Crossroads, Institute for Social Policy and Understanding (2017), https://www.ispu.org/wp-content/ uploads/2017/06/AMP-2017_Full-Report.pdf..... 21

Kevin L. Nadal et al., Subtle and Overt Forms of Islamophobia, VI(2) J. of Muslim Mental Health 15 (2012)

Pew Research Ctr., The Future of World

Religions: Population Growth Projections, 2010-2050, 6 (Apr. 2, 2015),

http://www.pewforum.org/2015/04/02/religious

-projections-2010-2050. 
Questions and Answers for Employees: Workplace Rights for Employees Who Are, or Are Perceived to Be, Muslim or Middle Eastern, Equal Employment Opportunity Commission, https://www1.eeoc.gov//eeoc/publications/musl im_middle_eastern_employees.cfm (last visited Mar. 22, 2018)

Sara Reardon, Health Toll of Immigration

Policies Begins to Emerge, 544 Nature 148 (Apr. 13, 2017)

Kristina Rizga, The Chilling Rise of

Islamophobia in Our Schools, Mother Jones (Jan. 26, 2016), http://www.motherjones.com/politics/2016/01/ bullying-islamophobia-in-american-schools/ .... 21

Cecile Rousseau et al., Trauma and Extended Separation from Family Among Latin American and African Refugees in Montreal, 64(1) Psychiatry 40 (2001).............................. 11

Dana Rusch \& Karina Reyes, Examining the Effects of Mexican Serial Migration and Family Separations on Acculturative Stress, Depression, and Family Functioning, 35(2) Hispanic J. Behav. Sci. 139 (2012)..................... 9

Muniba Saleem \& Srividya Ramasubramanian, Muslim Americans' Responses to Social Identity Threats: Effects of Media Representations and Experiences of Discrimination, Media Psychol. (Apr. 4, 2017), http://www.tandfonline.com/doi/full/10.1080/1 5213269.2017 .1302345 
Goleen Samari, Islamophobia and Public Health in the United States, 106(11) Persp. from the Soc. Sci. 1920 (Nov. 2016).................................. 24

Nina Shapiro, Aerospace Firm Electroimpact Agrees to Pay $\$ 485 k$ After AG Finds 'Shocking' Discrimination Against Muslims, Seattle Times, Mar. 23, 2017, https://www.seattletimes.com/seattlenews/times-watchdog/aerospace-coelectroimpact-agrees-to-pay-485000-after-agfinds-shocking-discrimination-againstmuslims/

Carola Suárez-Orozco et al., I Felt Like My Heart Was Staying Behind: Psychological Implications of Family Separations \& Reunifications for Immigrant Youth, 26(2) J. of Adolescent Res. 222 (2010)

David R. Williams et al., Health Effects of Dramatic Social Events-Ramifications of the Recent Presidential Election, 376(23) New Eng. J. of Med. 2295 (June $8,2017)$ $.21,23,24$ 


\section{INTERESTS OF AMICI CURIAE}

Amici curiae are the Service Employees International Union; American Federation of State, County and Municipal Employees; American Federation of Teachers; Communications Workers of America; National Education Association; International Brotherhood of Teamsters; International Union, United Automobile, Aerospace and Agricultural Implement Workers of America; United Farm Workers of America; and United Food and Commercial Workers.

Service Employees International Union (SEIU) is a labor organization of approximately two million working men and women in the United States, Canada, and Puerto Rico. ${ }^{1}$ SEIU's members include foreign-born U.S. citizens, lawful permanent residents, and immigrants authorized to work in the United States. Many of SEIU's members have mixedstatus families. As described below, SEIU members are directly affected by the challenged Proclamation.

American Federation of State, County and Municipal Employees (AFSCME), AFL-CIO, is a union of 1.6 million members in the United States and Puerto Rico, both in the public and private sectors, who share a commitment to service. AFSCME is participating in this case to advance its mission of helping all working people, including immigrants and people of color, achieve the American dream regardless of their identity. AFSCME is proud to

${ }^{1}$ All parties have consented to the filing of this brief. No counsel for a party authored any part of this brief and no counsel or party made a monetary contribution to its preparation or submission. Only the amici and their attorneys have paid for the filing and submission of this brief. 
represent members who have immigrated from Muslim-majority countries targeted by the illegal ban at issue, and/or who have family members who currently live in those countries, and staunchly opposes their being unconstitutionally subjected to the harms detailed in this brief. The public servants of AFSCME, and indeed all Americans, deserve better.

The American Federation of Teachers (AFT), AFLCIO, was founded in 1916 and today represents approximately 1.7 million members who are employed across the nation in K-12 and higher education, public employment, and healthcare. The AFT has a longstanding history of supporting and advocating for the civil rights of its members and the communities they serve. AFT members at a variety of institutions provide essential and necessary services, such as healthcare and education, to the public. Many of these members, especially those at institutions of higher education, are involved in global collaborations and in teaching and research duties that are being disrupted and threatened by the Proclamation. Additionally, a significant number of AFT members were born in, or have friends or family members in, countries named in the Proclamation. These members are directly impacted by the travel restrictions, which have affected their ability to work, travel, connect with, and care for their communities.

The Communications Workers of America (CWA), AFL-CIO, is an international labor union representing more than 700,000 workers in the telecommunications, media, manufacturing, airlines, and health care industries and in a wide variety of public sector positions in the United States, Canada, and Puerto Rico. CWA represents and advocates on 
behalf of workers of all creeds in the United States and abroad with respect to workplace rights and broader political and civil rights. In light of recent developments in U.S. domestic politics and federal policy that have targeted people of Islamic faith with discrimination, including those who may be members of the union or their family members, the CWA Convention resolved in 2017 to continue the union's "fight against discrimination in all its forms, including the targeting of people of the Islamic faith," and to "act in defense of and solidarity with those targeted by Islamophobia in our union, our workplaces, and our communities."

National Education Association (NEA) is the nation's largest professional association of educators representing approximately three million members, the vast majority of whom serve as educators, counselors, and education support professionals in our nation's public schools. NEA members work every day in their classrooms and schools to ensure that every student, no matter their race, religion, or national origin, receives a quality education that will allow them to grow into a productive member of our democratic society. The provision of a quality education depends on many factors but most fundamentally on ensuring that every student is treated equally and with respect. NEA members believe that discrimination and stereotyping based on religion must be eliminated in all educational settings, and therefore work every day to increase respect, understanding, acceptance, and sensitivity among students. The Proclamation has made that work harder, as it has fueled anti-Muslim hate speech and harassment in our nation's schools. 
The International Brotherhood of Teamsters (IBT) is a labor organization with more than 1.3 million members who are employed in a wide array of industries across the United States and Canada. Its members include immigrants and people with diverse backgrounds. The IBT, historically, has opposed all forms of invidious discrimination, including those described in this brief.

The International Union, United Automobile, Aerospace and Agricultural Implement Workers of America (UAW), AFL-CIO, has nearly one million active and retired members throughout the United States, Canada, and Puerto Rico. Since its founding in 1935, the UAW's membership has included immigrants from around the globe, and the UAW opposes any policies that discriminate against immigrants and non-immigrants alike based on their religion or national origin.

The UAW and its affiliated Local Unions represent workers in diverse sectors, including over 40,000 academic student employees and post-doctoral researchers at universities in the United States. Many of these workers are foreign-born nationals of Muslim-majority countries targeted by the Proclamation and are naturalized U.S. citizens or hold valid visas permitting them to study, live, and work in the United States. The Proclamation has disrupted their ability to travel freely into and outside of the country to visit family and loved ones and to conduct research related to their university employment and course of study, and prevented their family members from traveling to the United States.

United Farm Workers of America (UFW) represents thousands of migrant and seasonal farmworkers in various agricultural occupations 
throughout the country and has members of diverse racial, ethnic, and immigration backgrounds throughout the United States. UFW seeks to improve the lives, wages, and working conditions of agricultural workers and their families through collective bargaining, worker education, state and federal legislation, and through public campaigns. Since its founding in 1962 by Cesar Chavez, UFW has been dedicated to the cause of eliminating discrimination against farmworkers, Latinos, and any other groups that have been the target of unfair or unlawful treatment. UFW members, their families, and other farmworkers represented by UFW are directly affected by the challenged Proclamation.

United Food and Commercial Workers International Union (UFCW) is a labor organization that represents working men and women across the United States. UFCW's 1.3 million members work in a range of industries, with the majority working in retail food, poultry and meatpacking, food processing and manufacturing, and non-food retail. UFCW's objective is the elevation of its members through firstclass wages, hours, benefits, and working conditions. And that objective extends to the uplift of the families of its members.

UFCW and its predecessor unions have represented immigrants from around the world since the beginning of the last century, particularly workers in the packinghouses and stockyards. Immigrant workers continue to form a vital part of these and other workforces that UFCW represents. UFCW has members from the nations whose citizens are banned by the Proclamation. UFCW is aware that many of these workers experienced wrenching separation from their homelands due to war and 
6

famine. Accordingly, UFCW opposes religious and national origin discrimination and forced family separation. 


\section{INTRODUCTION AND SUMMARY OF ARGUMENT}

The issue in this case is whether Presidential Proclamation 9645, 82 Fed. Reg. 45,161 (Sept. 27, 2017) violates the Constitution or immigration laws of the United States. Like President Donald J. Trump's two prior Executive Orders on the same subject, the Proclamation continues to single out predominantly Muslim countries and follows presidential campaign promises and post-election assurances of a "Muslim ban."2

Amici submit this brief to demonstrate the devastating consequences of the President's actions for individuals across the United States. The challenged Proclamation targets individuals from Muslim-majority countries, including Iran, Libya, Syria, Yemen, Somalia, and Chad. Like the two Executive Orders that preceded it, the Proclamation separates families, including by leaving family members stranded in war-torn countries, and preventing parents and children from visiting each other. The President's most recent action also exacerbates discrimination and hostility by giving anti-Muslim intolerance the official imprimatur of the most important elected official in our democracy, and the Orders and Proclamation have been associated with increased anti-Muslim discrimination and violence. Myriad studies show that the forced separation of families and the religious intolerance countenanced by the Proclamation have concrete,

2 The prior Executive Orders are: Executive Order 13769, 82 Fed. Reg. 8977 (Jan. 27, 2017) (First Executive Order), and Executive Order 13780, 82 Fed. Reg. 13209 (Mar. 9, 2017) (Second Executive Order). 
negative effects on the physical and psychological well-being of targeted groups.

Millions of employees nationwide are united in the amici unions, and many union members and their families have been harmed by the Muslim travel ban put in place by the Proclamation and the Executive Orders that preceded it. Amici's members have been separated from their families, experienced the trauma and grief of this separation, and endured the hardship of ever-increasing hostility toward Muslims in the United States. The stories of twelve of these brave women and men, recounted below, are just some of the stories of the many union members and thousands of individuals across the country affected by the Proclamation. Their stories confirm the extensive research demonstrating the concrete harms, trauma, and stigma that the Proclamation inflicts on U.S. citizens and persons lawfully present in the United States.

\section{ARGUMENT}

I. The Challenged Proclamation Causes Irreparable Harm By Separating Citizens And Immigrants From Family Members Abroad.

\section{A. Compelled Family Separation Causes Negative Physical and Mental Health Consequences.}

Studies of transnational families document and explain how separation negatively affects parents and children as individuals as well as adversely affecting the bond between them. See, e.g., Sarah Horton, A Mother's Heart Is Weighed Down with Stones: A Phenomenological Approach to the Experience of Transnational Motherhood, 33 Culture, Med., \& Psychiatry 21, 21-40 (2009). The limits on physical 
interaction imposed by geographic separation make intimate relations between parents and children challenging and, consequently, the parent-child bond suffers. See Karlijn Haagsman et al., Transnational Families and the Subjective Well-Being of Migrant Parents: Angolan and Nigerian Parents in the Netherlands, 38:15 Ethnic \& Racial Stud. 2652, 265354 (2015). "This loss of intimacy and frustrated efforts to maintain close bonds . . can cause severe emotional distress for both parents and children who feel that the bond is deteriorating." Id. at 2654 .

The pain of separation is long-lasting for parents. One study found that parents recalled the circumstances of their family's migration process and "emotionally laden details of their family separations" even after living in the United States for ten years or more. Dana Rusch \& Karina Reyes, Examining the Effects of Mexican Serial Migration and Family Separations on Acculturative Stress, Depression, and Family Functioning, 35(2) Hispanic J. Behav. Sci. 139,151 (2012). The pain of separation is also often accompanied by feelings of guilt. Haagsman, supra, at 2654; see also id. (women separated from children "feel guilty, ashamed and stigmatized"); Jeanne Miranda et al., Depression Among Latina Immigrant Mothers Separated from their Children, 56(6) Psychiatric Servs. 717, 720 (2005) (finding that immigrant Latinas separated from their children are at greater odds for depression than women not separated).

Not surprisingly, family separation inflicts serious harm on children as well. One 14-year-old girl described her experience this way: "The day I left my mother I felt like my heart was staying behind." Carola Suárez-Orozco et al., I Felt Like My Heart Was 
Staying Behind: Psychological Implications of Family Separations \& Reunifications for Immigrant Youth, 26(2) J. of Adolescent Res. 222, 240 (2010). The forced separation is damaging to children even though parents may try to maintain contact through letters, phone calls, and contributions to their children's material well-being. Id. Children face difficult experiences not only when they are first separated from their parents but even later at reunification (if it occurs), when children can feel disoriented, estranged from their parents, mistrustful, and uncomfortable in their new family dynamic (sometimes including new siblings). Id. at 242-45. Children also experience a sense of loss all over again as they are separated from their interim caretakers. Id.

Studies show that compelled family separation has meaningful physiological consequences as well. Family separation is almost inevitably accompanied by "[p]rolonged exposure to serious stress-known as toxic stress," which the American Academy of Pediatrics has warned "can harm the developing brain and negatively impact short- and long-term health." Sara Reardon, Health Toll of Immigration Policies Begins to Emerge, 544 Nature 148 (Apr. 13, 2017).

Further, "[a] number of clinical studies . . . show that there are substantial negative psychological repercussions for immigrant children and youth who have been separated from their parents." SuárezOrozco, supra, at 227. Children who feel abandoned by their parents may respond with despair and detachment, id., and separated children are more likely to report symptoms of anxiety and depression in the initial years after migration than children who were not separated from their parents. Id. at 222. 
For individuals who come to the United States fleeing persecution, civil wars, and bombings, the effects of family separation are particularly severe because "the family plays a central role in modulating the processes that influence the aftermath of trauma." Cecile Rousseau et al., Trauma and Extended Separation from Family Among Latin American and African Refugees in Montreal, 64(1) Psychiatry 40, 57 (2001). The family is "an anchor for both emotion and identity" and aids those fleeing persecution and trauma, who otherwise "often feel estranged and alienated." Id. For individuals able to stay together with family, the presence of close relatives can even "seem to transform adversity into a source of strength, perhaps by aiding in the rebuilding of a meaningful universe." $I d$.

By contrast, individuals who have fled their home countries and are separated from their loved ones feel "more disoriented than those living with at least part of their families" and "seem more overwhelmed by unspeakably painful memories." Id. at 56. For individuals "who have had traumatic experiences, extended separation from family members may serve as a continuing link to an unbearable past ...." Id. at 41 . These individuals are also "tormented daily by worry about what will become of the family members still overseas," $i d$. at 49 , and feel significant guilt about having left their families behind with threats of reprisals looming over their family members, $i d$. at 41.

\section{B. Amici's Members Have Suffered the Harm of Forced Family Separation.}

Amici's members have described the difficult psychological consequences of being separated from 
their families and the harm that they have experienced as a result of the President's travel bans. ${ }^{3}$

Dr. K.Z. and Dr. N.N.

Dr. K.Z., a fourth-year internal medicine resident at a New York teaching hospital in Brooklyn, New York, and a member of SEIU's Committee of Interns and Residents (CIR), fled persecution in Iran and entered the United States with refugee status in 1998. Although born in Iran, Dr. K.Z. became a naturalized U.S. citizen more than a decade ago. Now, as a resident, Dr. K.Z. serves low-income patients from diverse backgrounds, including Orthodox Jews and people of Arab, Chinese, Latin, Russian, Caribbean, and South and Southeast Asian descent. When Dr. K.Z. completes his residency, he intends to continue working in a U.S. hospital with a diverse group of patients providing critical care and treatment to patients suffering from cancer.

One year ago, Dr. K.Z. married Dr. N.N., a gastroenterology fellow who works at the same hospital and is also a CIR member. Dr. N.N. is a citizen of Iran and a United States legal resident. As the couple planned their wedding, they did everything in their power to ensure that Dr. N.N's Iranian father would be able to come to the United States and participate in the wedding ceremony.

After issuance of President Trump's Second Executive Order, Dr. N.N's father was denied permission to enter the United States. The couple

3 The individuals whose stories are told here consented to having their experiences recounted in this brief, and records of the interviews conducted with them are on file with counsel. Some participants chose to maintain a measure of anonymity by using first names or initials only. 
sought and received the assistance of their congressional representative, but even that did not help, and Dr. N.N's father was unable to give his daughter away during the wedding ceremony. Dr. K.Z. says that his "wife was heart-broken that her father, the parent who had raised her, could not attend our wedding or participate in the wedding rituals that meant so much to her. Her father's absence tainted what was to be one of the best days of our lives."

Dr. K.Z. was deeply disturbed and shaken by the travel ban's effect on his life. "The United States welcomed and encouraged me and I truly believed that the words on the Statute of Liberty were meant for me." But "[i]t has been a crushing personal disappointment to learn that the citizens of certain countries, people like my father-in-law, were no longer welcome."

\section{Mohammad Al Zayed}

Mohammad Al Zayed was forced to leave behind his father and other relatives when he fled Syria. Mohammad currently works at O'Hare International Airport as a janitor and lives on the far North Side of Chicago with his wife and three children; he is also a member of SEIU's Airport Workers United campaign. He has two young adult children and a son in elementary school.

Before fleeing Syria, Mohammad and his family lived in a suburb outside Damascus. When unrest began to approach their community, the family fled into the capital. Eventually, the textile factory where Mohammad worked was destroyed in the fighting, and his children could no longer go to school because of the danger. Once the war reached Damascus, the 
family left Syria for Jordan to escape the violence and bombings.

"We can't even explain it," Mohammad said of the violence and destruction he and his family witnessed in Syria. "Shelling. Killing. Street fighting. Nobody knows who's fighting who, but everybody dying is innocent people."

Mohammad was relieved when he arrived with his family in the United States, where he hoped there would be more opportunity for his children. His eightyear-old son is in school, already speaks English, and claims math as his favorite subject. Mohammad's adult son has joined him in working at O'Hare. Mohammad feels fortunate to work alongside colleagues at O'Hare who represent over 100 nationalities. He says it is "very nice" to be in a welcoming environment where he can observe his religion, as he did during the month of Ramadan.

Mohammad, however, worries about relatives left behind and about whether he will see them again. Mohammad's two brothers, father, and stepmother remain in Syria, and he has not seen them since 2012. His father is in his late eighties and has health problems. If the Muslim travel ban is upheld, Mohammad may never see his father again. Mohammad's wife also has eleven sisters and four brothers, some of whom are in Syria and Jordan. Mohammad's daughter is married to a Jordanian citizen, and she worries that if her new husband is not able to come to the United States, she may have to return to Jordan and then be barred from reentering the United States.

Mohammad believes that the Trump Administration's Muslim travel ban "is not right." 
Syrians are simply seeking a better life. He says: "It's very sad. Who would want to leave their home if they don't have to? People are running for their lives."

\section{Abdi}

Abdi, a 33-year old worker at Minneapolis-St. Paul International Airport and member of SEIU's Airport Workers United campaign, suffers from the daily torment of worrying about his family members in Somalia.

Before coming to the United States, Abdi spent several years in refugee camps with his mother and siblings. While Abdi lived in the camps, his education was interrupted several times. But once Abdi arrived in the United States at the age of 18, he completed high school and earned a bachelor's degree at Metropolitan State University in Minneapolis. Abdi eventually became a naturalized American citizen and was able to bring his wife and one of his three children to the United States.

Unfortunately, visas for Abdi's two eldest children were not granted when his wife's visa was granted. As a result, they still live in Somalia with Abdi's mother, who cares for them even though she is in her sixties. Abdi sends her money for their care, but he fears they will not be able to travel to the United States to reunite with him if the Proclamation is upheld. He says, "I can't stop thinking about them. I have to be able to do this."

Abdi also worries about his and other relatives' ability to travel as Somali-born United States citizens. One of his aunts, an American citizen, wants to travel home to visit a sick uncle but worries about being detained on her way back. He says, "What kind of American value is this, to keep families apart?" 


\section{Marwan}

Marwan, a senior organizer for SEIU, where he has worked for more than a decade, was born in Yemen and is a naturalized U.S. citizen. As a union organizer, he works to help airport employees at O'Hare International Airport. Every day he interacts with employees who, like him, came to the United States as immigrants, grateful for a better life and hopeful that they would be reunited with their families. The Muslim ban changed that. As he says: "This won't make America safe, only tear families apart."

The first person in Marwan's family to arrive in the United States was his father. Marwan's father reunited the family by bringing his brothers, Marwan, Marwan's mother, and Marwan's siblings one by one to the Detroit area over the course of several decades. Marwan came to the United States in 1989 from Yemen and became a citizen in 1991. He is married with five children, aged 18, 13, 9, 6, and 5.

Many members of Marwan's and his wife's extended families remain in Yemen, where a civil war is raging. One of Marwan's brothers returned to Yemen before becoming an American citizen and lives in the capital of Sana'a with his wife and five children. About a year ago an airstrike hit a military compound 200 yards from his brother's house, shattering all the windows in the neighborhood. Marwan's nephew's arm was injured in the blast. Marwan's family's ancestral village has also been the target of rebel activity and air strikes. Nine relatives, including two of his cousins, have been killed in the last several years. Marwan's wife's three brothers and three sisters also all live in Yemen. An elderly aunt in her eighties, who helped raise Marwan as his father 
worked to bring him to the United States, remains there as well and requires care. Marwan worries for the safety of all his and his wife's extended family members. He says: "I think about this every day and ask myself, "How do I bring them here?"'

The challenged Proclamation will make it impossible for Marwan to reunite his family the way his father did in the past. "If my dad hadn't come to the United States, I would be there right now and living under terror. I would be stuck." Marwan now worries that more of his family members, for whom he feels responsible, will be hurt or harassed by the warring factions in his home country.

\section{Majd}

Majd is a homecare worker, member of SEIU Local 2015, and naturalized U.S. citizen. Majd lives in San Jose, California, with her husband, her two adult children, and her 90-year-old mother, all of whom are also U.S. citizens. Majd was born and educated in Syria, where she worked as an agricultural engineer until she came to the United States about 25 years ago.

Most of Majd's extended family emigrated from Syria to the United States, with the exception of a nephew who is in the midst of processing his application for legal permanent residency. Majd's nephew lives alone in Damascus where he fears leaving his home. Although he is not affiliated with any political organizations, he was arrested, interrogated, and jailed for several weeks by Syrian government agents. Recently, he was arrested and pursued by government agents for a third time. Those experiences, combined with Syria's brutal civil war 
and the departure of all of his family members, has plunged him into a severe depression.

Majd and her elderly mother, her nephew's grandmother, are desperate for her nephew to join them in the United States, especially in light of the health problems they face. Majd has been diagnosed with breast cancer, and her husband is being treated for prostate cancer. Majd's mother suffers from diabetes, high blood pressure, heart problems, and arthritis. Because the travel ban permanently halts Syrian immigration, Majd's mother fears that the travel ban will prevent her from seeing her grandson before she dies. Majd worries about both her nephew and the effect on her mother of his inability to travel to the United States.

$* * *$

The result of the Muslim ban's forced separation of families is the psychological harm documented in the social science literature and experienced by amici's members like Dr. K.Z., Mohammad, Abdi, Marwan, and Majd. Such irreparable psychological harm is precisely what Congress sought to avoid when it enacted policies embodied in the Immigration and Nationality Act to preserve the family unit. See Legal Assistance for Vietnamese Asylum Seekers $v$. Dep't of State, 45 F.3d 469, 471-72 (D.C. Cir. 1995). The District Court's injunction is necessary to prevent this harm to amici's members across the country.

II. The Proclamation Sends A StateSponsored Message That Promotes Anti-Muslim Hostility, Discrimination, And Stigma.

In addition to causing harm through forced family separation, the challenged Proclamation, like the two Executive Orders that preceded it, promotes the 
stigmatization of the Muslim faith and condones and encourages anti-Muslim hostility and violence.

\section{A. The Muslim Travel Ban Has Led to Increased Violence and Discrimination Against Muslims.}

A persistent theme in anti-Muslim discrimination is the allegation and assumption that Muslims are not "real" Americans-and are perpetual outsiders and aliens in their own land, despite viewing themselves as completely American. See, e.g., Kevin L. Nadal et al., Subtle and Overt Forms of Islamophobia, VI(2) J. of Muslim Mental Health 15, 22, 27-28 (2012). The anti-Muslim rhetoric used by President Trump both before and after his election has encouraged such erroneous claims, and the targeting of predominantly Muslim countries for disfavored treatment in the Proclamation, as with the two prior Executive Orders, furthers and deepens the portrayal of Muslims as unwelcome outsiders.

Indeed, the Muslim travel ban has been seen by many as establishing a false and dangerous equivalence between Islam and violent terrorism, see generally Rebecca A. Clay, Islamophobia: Psychologists Are Studying the Impact of Anti-Muslim Sentiment and Exploring Ways To Prevent It, 48(4) Monitor on Psychol. 34 (Apr. 2017), even though Islam is one of the world's major religions and the faith tradition of $23 \%$ of the world's population. ${ }^{4}$ President Trump himself cited the September 11 attacks as justification for the Second Executive

4 Pew Research Ctr., The Future of World Religions: Population Growth Projections, 2010-2050, 6 (Apr. 2, 2015), http://www.pewforum.org/2015/04/02/religious-projections2010-2050. 
Order even though none of the men behind those attacks (or any subsequent, fatal terrorist attack in the United States) hailed from the Order's targeted countries. See id. The reference to September 11 makes sense only if one links Muslims generally with terrorism. Having that equivalence communicated by the White House and embodied in official policy gives people tending toward Islamophobia the permission to act on their biases.

The 2017 second quarterly report of the Council on American-Islamic Relations (CAIR) shows that the number of anti-Muslim hate crimes in the first half of 2017 spiked $91 \%$ as compared to the same period in 2016; the third quarterly CAIR report also indicates a rise in hate crimes over the same period last year. See 2017 on Track to Becoming One of the Worst Years Ever for Anti-Muslim Hate Crimes, CAIR (Oct. 11, 2017), http://islamophobia.org/articles/ 209-2017-ontrack-to-becoming-one-of-the-worst-years-ever-foranti-muslim-hate-crimes.html; CAIR 3rd Quarter Civil Rights Report Shows Rise in Hate Crimes Over Same Period Last Year, Moderate Decline in Total Cases, CAIR (Oct. 25, 2017), http://cair.com/presscenter/press-releases/14715-cair-3rd-quarter-civilrights-report-shows-rise-in-hate-crimes-over-sameperiod-last-year-moderate-decline-in-totalcases.html.

In addition to the rise in all hate crimes, there has been a noticeable escalation in anti-Muslim violence. Recent incidents of fires, Nazi graffiti, and broken glass at an Iraqi-American business in downtown Flagstaff, Arizona, followed the ripping up of copies of the Quran at a Tucson mosque in March of 2017, which followed broken windows at a Middle Eastern bakery in Phoenix shortly before that. See CAIR Calls 
for Hate Crime Probe for Racist Harassment Targeting Tenn. Muslim Girls, Knife Attack on Father, Threat to Kill Entire Family, CAIR (Oct. 25, 2017), https://www.cair.com/press-center/pressreleases/14735-cair-calls-for-hate-crime-probe-ofracist-harassment-targeting-tenn-muslim-girls-knife -attack-on-father-threat-to-kill-entire-family.html. Later in the year, Muslim girls in Tennessee suffered harassment, a knife attack on their father, and a threat to kill the entire family. Id. And in December of 2017, the FBI arrested a Florida man when he revealed his plans to "shoot up" the Islamic Center of Northeast Florida in order, in his words, to "give these freaking people a taste of their own medicine." AntiMuslim Activities in the United States, New America, https://www.newamerica.org/in-depth/anti-muslimactivity/ (last visited Mar. 22, 2018).

Disturbingly, the Southern Poverty Law Center found that post-election incidents of harassment and intimidation have been commonly reported in K-12 schools. See David R. Williams et al., Health Effects of Dramatic Social Events-Ramifications of the Recent Presidential Election, 376(23) New Eng. J. of Med. 2295, 2296 (June 8, 2017). Overall, Muslim students report being bullied four times more than other students. See Dalia Mogahed \& Youssef Chouhoud, American Muslim Poll 2017: Muslims at the Crossroads, Institute for Social Policy and Understanding at 4, 12 (2017), https://www.ispu. org/wp-content/uploads/2017/06/AMP-2017_Full-

Report.pdf. Incidents abound of Muslim and Middle Eastern students being called ISIS or terrorists, or being subjected to harassment such as having their hijabs (religious head coverings) pulled off by other students. See, e.g., Kristina Rizga, The Chilling Rise of Islamophobia in Our Schools, Mother Jones (Jan. 
26, 2016), http://www.motherjones.com/politics/2016/ 01/bullying-islamophobia-in-american-schools/.

Anti-Muslim discrimination and bias also has a significant impact on the workplace, and can lead to workers being fearful and distrustful of their employers. A rise in anti-Muslim harassment prompted the U.S. Equal Opportunity Employment Commission to issue guidance to workers who may be discriminated against because they wear a hijab, or who are called names like "the local terrorist," "fanatic," and "ISIS." See Questions and Answers for Employees: Workplace Rights for Employees Who Are, or Are Perceived to Be, Muslim or Middle Eastern, Equal Employment Opportunity Commission, https://www1.eeoc.gov//eeoc/publications/muslim_mi ddle_eastern_employees.cfm (last visited Mar. 22, 2018); see also Nina Shapiro, Aerospace Firm Electroimpact Agrees to Pay $\$ 485 k$ After AG Finds 'Shocking' Discrimination Against Muslims, Seattle Times, Mar. 23, 2017, https://www.seattletimes. $\mathrm{com} / \mathrm{seattle-news/times-watchdog/aerospace-co-}$ electroimpact-agrees-to-pay-485000-after-ag-findsshocking-discrimination-against-muslims/ (describing Washington State findings that employer had equated Muslims and immigrants from predominantly Muslim countries with terrorists). Research further suggests that anti-Muslim discrimination is related to lower levels of job satisfaction, which also affects productivity. Clay, supra, at 34 .

\section{B. Anti-Muslim Hostility and Discrim- ination Adversely Affects Mental and Physical Health.}

The hostility and discrimination encouraged by the Proclamation's targeting of predominantly 
Muslim countries also have negative physical and mental health consequences for those who feel targeted. As explained recently in the New England Journal of Medicine, "communities who feel vulnerable because they belong to a stigmatized, marginalized, or targeted group" can experience negative health effects as a result. Williams, supra, at 2295. With respect to people of Middle Eastern descent in particular, a post-September 11 study conducted in the Detroit area "found that experiences of discrimination and abuse . . . were positively associated with physiological distress . . . ." Id. at 2296. Another study found that Arab-American women in California experienced increased risk of low-birth-weight babies or pre-term births in the six months after September 11; women in other racial and ethnic groups did not experience any similar effects. Id.

Anti-Muslim discrimination also has adverse effects on American Muslims' mental health. Research has found an association between religious discrimination and depression in American Muslim women. See Dena Hassouneh, Anti-Muslim Racism and Women's Health, 26(5) J. of Women's Health 401 (2017). Another study of Muslim Americans found that those who reported experiencing discrimination were more likely to distrust, display negative attitudes, and avoid social interactions with the larger community. See Muniba Saleem \& Srividya Ramasubramanian, Muslim Americans' Responses to Social Identity Threats: Effects of Media Representations and Experiences of Discrimination, Media Psychol. (Apr. 4, 2017), http://www.tand fonline.com/doi/full/10.1080/15213269.2017.1302345. Moreover, children who are bullied or harassed due to their Muslim faith or Middle Eastern ancestry 
perform worse academically and have higher rates of stress, depression, and anxiety. See Mislabeled: The Impact of School Bullying and Discrimination on California Muslim Students, CAIR California at 9-10 (2015), https://ca.cair.com/sfba/wp-content/uploads/ 2015/10/CAIR-CA-2015-Bullying-Report-Web.pdf; see also Sawssan R. Ahmed et al., A Structural Model of Racial Discrimination, Acculturative Stress, and Cultural Resources Among Arab American Adolescents, 48 Am. J. Cmty. Psych. 181, 186 (2011).

In addition to studies specifically focused on Muslim communities, years of research confirms the negative health effects experienced by people who are the targets of discrimination. One 2015 study found an elevated risk of death among adults residing in communities where levels of racial prejudice were high, Williams, supra, at 2296, and immigrant children exposed to discrimination have been found to suffer adverse psychological consequences, David K. Androff et al., U.S. Immigration Policy and Immigrant Children's Well-being: The Impact of Policy Shifts, 38(1) J. of Soc. \& Welfare 77, 90 (2011). Everyday experiences of discrimination have been associated with coronary artery calcification, high blood pressure, poor sleep, and depression, distress, and anxiety. Goleen Samari, Islamophobia and Public Health in the United States, 106(11) Persp. from the Soc. Sci. 1920, 1921 (Nov. 2016). Research also indicates that the stress associated with discrimination adversely affects health not only through actual experiences but also because of rumination, vigilance, and worry over potential exposure to discrimination and harassment. See Williams, supra, at 2297. 


\section{Amici's Members Have Suffered from the Proclamation's Anti-Muslim Message.}

Amici's members have been harmed by the Proclamation's state-sponsored anti-Muslim message and the increased hostility and stigma that it has incited. Amici's members, their families, and their communities have been placed in physical danger, lost their jobs, and struggled daily with the stress and fear of being seen as terrorists in their own homes.

K.K.

K.K., an Iranian citizen and F-1 visa holder currently working in the United States as a postdoctoral researcher, has experienced workplace discrimination as a direct result of the Muslim ban. In January 2017, K.K. was working at a prestigious American university, where she was part of a UAW campaign to organize postdoctoral researchers. After the First Executive Order was issued, K.K. was suddenly dismissed from her appointment. She had never received any negative performance reviews or feedback, and she was previously provided with a letter promising funding for her position through at least May 31, 2017. K.K.'s supervisor told her that the funding on the grant she was working on had dried up, but a colleague told K.K. that the supervisor confided the real reason for her dismissal was that the supervisor was concerned about having an Iranian citizen working on the research project after the issuance of the First Executive Order.

Following her dismissal from the university, K.K. was able to secure a new position at a university in another state. However, she lost several months of work, which, in addition to causing financial strain, delayed her ability to complete her research. She 
estimates that moving to another university and another state cost her around $\$ 5,000$ in out-of-pocket expenses.

\section{Safyia Yonis}

Safyia Yonis is a naturalized American citizen who was born in Somalia, and she fears that the violence incited by the Muslim ban will affect her family. She has lived in Minneapolis for more than 20 years, where she works as a janitor in a government building and is a member of SEIU Local 26. Safyia and her husband, who was also born in Somalia, have seven children under the age of 18 who were born in the United States.

When civil war broke out in Somalia in 1991, Safyia fled to Kenya where she lived in a refugee camp. She says that life there was "very, very difficult," with no access to education or healthcare. When Safyia arrived in the United States two years later, she felt safe and grateful she could go to see the doctor, attend school, and work.

Since the Muslim ban was announced, however, Safyia has felt increasingly afraid of violence and harassment. Her sister and brother-in-law attend the mosque that was bombed on August 5, 2017 in the suburb of Bloomington. Safyia worries in particular that her daughter, who is in high school and wears a hijab, could be a target for harassment. Safyia feels her daughter should not have to live in fear: "She is an innocent; she has done nothing wrong."

A.G. and C.A.

A.G. and C.A. are educators. A.G. is a teacher in Virginia, a member of NEA, and a parent of three children. She reports that all three of her children were bullied in school for being Muslim. Recently, she 
has observed an increased level of fear among Muslim students at the school where she works. C.A. is a middle school teacher in Utah and a member of NEA. Since the first Executive Order was issued, she has had to confront anti-Muslim harassment at her school. Students have "ripp[ed] hijabs off the heads of Muslim girls in school," and several of her female Muslim students have become "very quiet and withdrawn."

\section{A.F.}

A.F. is a member of UAW Local 5810 and an Iranian citizen. A.F. came to the United States for graduate studies in 2011 and obtained his Ph.D. in chemical engineering in 2016 from a prestigious American university. He currently works as a postdoctoral researcher at the University of California's Lawrence Berkeley National Laboratory (LBNL). After being offered the position at LBNL, A.F. underwent an extensive, nine-month-long background check conducted by the Department of Energy.

Since the signing of President Trump's First Executive Order, A.F. has suffered from chronic stress and has felt unwelcome in the country where he has successfully lived, worked, studied, and paid taxes for six years. A.F. applied for a green card under a national interest waiver and holds a singleentry visa. He fears that if he leaves the United States he will not be permitted to reenter. Prior to the issuance of the First Executive Order, A.F.'s parents visited him in the United States, but now A.F. fears it is impossible for them or other members of his family to obtain a visa to visit the United States. In addition, A.F.'s work is affected because he fears it is impossible for him to travel to attend annual 
conferences, including the International Conference on Thermoelectrics, which are crucial for scientists in his field. Because of the travel ban, A.F. fears that Iranian nationals like him are "doomed" to live in limbo.

\section{A.T.}

A member of UAW Local 4121, A.T. has been studying in the United States for the last four years and also works as an academic student employee. He holds a single-entry F-1 visa and fears that he may not be able to complete his studies in a Ph.D. program at the University of Washington because he is an Iranian citizen targeted by the Muslim ban. Even if he is able to remain in the United States, A.T. is also deeply concerned that the hostility generated by the travel ban will inhibit his ability to complete his Ph.D. in a timely manner and begin his professional career.

A.T. was in Iran visiting family in January 2017 when the First Executive Order was issued. He was initially unable to secure a visa to return to his home and studies in the United States. A.T. contacted UAW Local 4121, which worked to assist him in getting back to the United States. As a result of assistance from Washington State's governor, one of its senators, and a congressional representative, A.T. was lucky to be able to reenter the United States and resume his Ph.D. program while the First Executive Order was enjoined. He is currently unable to leave the United States again while he completes his studies; he has no family in the United States, and due to the Proclamation, his parents, who live in Iran, are unable to visit him here. 
The experiences of amici's members illustrate the wide-ranging harms inflicted by the anti-Muslim message sent by President Trump's Proclamation, including discrimination and harassment in school, in the workplace, and in members' daily lives.

\section{CONCLUSION}

For the foregoing reasons, this Court should affirm the preliminary injunction below, except as to its limitation to persons with a bona fide relationship with an individual or entity in the United States.

Dated: March 27, 2018 Respectfully submitted,

NiCOLE G. BERNER

DEBORAH L. SMITH

LEO GERTNER

SERVICE EMPLOYEES

INTERNATIONAL UNION

1800 Massachusetts

Ave., NW

Washington, DC 20036 debbie.smith@seiu.org Attorneys for Amicus

Curiae SEIU

BARBARA J. CHISHOLM

Counsel of Record

KRISTIN M. GARCÍA

ALTSHULER BERZON LLP

177 Post Street, Ste. 300

San Francisco, CA 94108

(415) 421-7151

bchisholm@altber.com

Attorneys for Amici Curiae

Counsel continued on next page. 
JUDITH RIVLIN

AMERICAN FEDERATION OF STATE, COUNTY AND MUNICIPAL EMPLOYEES 1101 17th St., NW, Suite 900

Washington, DC 20036 jrivlin@afscme.org Attorney for Amicus Curiae AFSCME

DAVID J. STROM AMERICAN FEDERATION OF TEACHERS, 555 New Jersey Ave., NW

Washington, DC 20001 dstrom@aft.org Attorney for Amicus Curiae AFT

JODY CALEMINE

COMMUNICATIONS WORKERS OF AMERICA 501 3rd St., NW Washington, DC 20001 jcalemine@cwaunion.org Attorney for Amicus Curiae CWA
ALICE O'BRIEN

EMMA LEHENY

LUBNA A. ALAM

NATIONAL EDUCATION

Association

$120116^{\text {th }}$ Street, NW, Suite 819

Washington, D.C.

20036-3290

aobrien@nea.org

Attorneys for Amicus

Curiae NEA

NiRAJ R. GANATRA

AVA BARBOUR

INTERNATIONAL UNION, UNITED AUTOMOBILE, AEROSPACE AND

AGRICULTURAL IMPLEMENT WORKERS OF AMERICA (UAW) 8000 E. Jefferson Ave. Detroit, MI 48214 nganatra@uaw.net abarbour@uaw.net Attorneys for Amicus Curiae UAW

MARIO MARTÍNEZ MARTÍNEZ AGUILASOCHO \& LYNCH, APLC 1527 19th St., Suite 332 Bakersfield, CA 93301 mmartinez@farmworker law.com Attorney for Amicus Curiae UFW 
NiCHOLAS CLARK

UNITED FOOD AND

COMMERCIAL WORKERS

1775 K Street, NW

Washington, DC 20006

nclark@ufcw.org

Attorney for Amicus

Curiae UFCW 




